\title{
PEMBENTUKAN KARAKTER ANAK MELALUI PERMAINAN TRADISIONAL CIM-CIMAN
}

\author{
Fauzi \\ e-mail: fauzistainpwt@gmail.com \\ Fakultas Tarbiyah dan IImu Keguruan IAIN Purwokerto \\ JI. Jend A. Yani No. 40A Purwokerto
}

\begin{abstract}
Abstrak: Penelitian ini bertujuan untuk mendeskripsikan dan merekonstruksi eksistensi permainan anak tradisional cim-ciman, serta untuk menemukan peran substantif permainan anak tradisional cimciman dalam perkembangan dan pembentukan karakter anak usia dini. Penelitian dilakukan pada tahun 2012 di Kabupaten Banyumas Jawa Tengah dengan menggunakan pendekatan penelitian kualitatif. Pengumpulan data menggunakan teknik observasi terlibat, dengan bantuan lembar observasi sebagai acuan fokus pengamatan. Data dianalisis dengan teknik analisis kualitatif model Miles dan Huberman. Hasil penelitian menunjukkan bahwa permainan Cim-ciman dapat dipergunakan untuk (a) melatih dan menstimulasi perkembangan anak dalam beragam aspek secara holistik-integratif, baik aspek fisik motorik, bahasa, kognitif, sosial emosional, dan moral; (b) untuk menanamkan dan membentuk nilai-nilai budaya dan membangun karakter anak seperti jujur, disiplin, kreatif, mandiri, tanggungjawab, kepedulan sosial, kerja keras, semangat, menghargai prestasi, bersahabat atau komunikatif, cinta damai, dan musyawarah. Penelitian ini memberikan saran bahwa perlunya rekonstruksi dan revitalisasi permainan anak tradisional (dolanan anak) yang tersebar di seluruh nusantara dengan segala kekhasan budayanya untuk selanjutnya dijadikan sebagai menu pendidikan anak usia dini.

Kata kunci: permainan tradisional, anak usia dini, Cim-Ciman, nilai, budaya, karakter.
\end{abstract}

\section{CHILD CHARACTER BUILDING THROUGH TRADITIONAL GAME 'CIM-CIMAN”}

\begin{abstract}
This research aimed in describing and reconstructing the existence of Cim-ciman as traditional child game, and also on founding the substance role of, in developing and constructing the character of child in early age. This research conducted in the district of Banyumas in Central Java and used qualitative research approach. Data collection used participation observation technique which is supported by observation sheet as observation focus standard. The data was analysed through Miles and Huberman model of qualitative analysis technique. The result showed that the game of Cim-ciman can be applied on practicing and stimulating child development in various aspect as holistic and integrative point of view, either motoric physical aspect, language, cognitive, social, emotional, and moral. Besides that, it can be used in growing and forming cultural values and constructing child character, for example, honesty, discipline, creativity, integrity, responsibility, social solidarity, hard work, spirit, achievement appreciation, friendship or communication, peace keeping, and dialogue. In this case, the reconstruction and revitalization of child traditional game (dolanan for child), that are spread in all parts of Indonesia with their cultural uniqueness, are needed, and then to be made as early education menu.
\end{abstract}

Keywords: traditional game, early childhood, Cim-ciman, value, culture, character

\section{PENDAHULUAN}

Arus besar globalisasi telah membawa pengaruh terjadinya pergeseran nilai hidup yang dianut oleh "warga bangsa". Dengan bantuan media-media global, nilai-nilai dan budaya Barat masuk dan menyatu dalam kehidupan bangsa Indonesia. Perlu disadari bahwa adopsi teori, nilai, dan budaya Barat yang dikembangkan berbasiskan pada akar budaya yang berbeda dengan yang 
dimiliki oleh bangsa Indonesia berdampak pada terjadinya krisis dan rusaknya karakter pada manusia Indonesia.

Nilai-nilai yang berakar pada kepribadian dan jatidiri yang menjadi karakter unggul bangsa Indonesia semakin hilang. Praktek kehidupan kebangsaan yang terjadi cenderung tidak sesuai dengan budaya adiluhung yang telah tumbuh dan berkembang di masyarakat. Karakter dan budaya gotong royong, etos ketelatenan, keuletan, kebersamaan, kesantunan, toleransi, dan kejujuran mulai sirna dan menjadi barang langka yang semakin sulit ditemukan. Justru yang tumbuh subur budaya instan, individualisme, materialisme, konsumerisme, hedonisme, dan sikap intoleran.

Kondisi krisis sebagaimana paparan di atas sejatinya menjadi cerminan adanya problem yang tengah melanda dunia pendidikan di Indonesia. Saat ini pendidikan sedang mengalami disorientasi sebagai akibat kuatnya hegemoni teori dan nilai budaya global ("Barat") dalam dunia pendidikan. Watak dan wajah ke-Indonesia-an semakin sulit ditemukan dalam praktek pendidikan nasional. Kondisi ini sungguh memprihatinkan, perlu ada upaya serius untuk mengembalikan pendidikan dengan semangat ke-Indonesiaan dengan segala keragamannya, tentu saja dengan tetap bervisi global (think globally, act locally).

Mohammed 'Abed Al-Jabiri (2003), seorang ilmuwan dari Maroko mengungkapkan bahwa perubahan harus berangkat dari dalam, dari tradisi sendiri, bukan dengan meminjam tradisi orang lain. Tawaran Al-Jabiri sebagai tawaran yang sangat menarik untuk direfleksikan dalam konteks kehidupan kebangsaan, sebagai bangsa yang kaya akan kebudayaan lokal dengan segala keunikan dan keragamannya.

Tawaran Al-Jabiri di atas tidak bisa dilepaskan dari sistem pendidikan pada suatu bangsa yang melandasi praktik pendidikannya untuk membangun sumber daya manusia (SDM). Membangun SDM yang bermartabat tentunya tidaklah harus menafikan keberadaan kearifan lokal, karena pendidikan yang kuat berakar pada pendidikan yang berangkat dari nilai kearifan lokal dan menjadikan lokalitas sebagai sumber pembangunan anak bangsa.

Kebudayaan akan menentukan bangunan sosial suatu bangsa (Barker, 2004) sehingga pembentukan karakter suatu bangsa harus bersumber dari nilai budaya masyarakatnya. Dengan demikian, pendidikan yang tidak dilandasi oleh kearifan lokal dapat mengakibatkan peserta didik tercerabut dari akar budayanya. Ketika hal ini terjadi, generasi anak bangsa tidak akan mengenal budayanya dengan baik sehingga menjadi orang "asing" dalam lingkungan budayanya. Selain menjadi orang asing, yang lebih mengkhawatirkan akan uncul generasi masa depan yang tidak menyukai budayanya. Pengembangan pendidikan dalam rangka melahirkan generasi baru yang berbudaya ke-Indonesiaan dapat berhasil dengan optimal jika dilakukan semenjak anak usia dini dan dilakukan dengan cara yang sesuai dengan karakteristik tumbuh kembang anak. Berbagai hasil kajian terkini menyatakan bahwa pendidikan yang diberikan pada anak semenjak usia dini sebagai periode sensitif dan usia emas akan memberikan dampak yang sangat signifikan bagi tumbuh dan berkembangnya anak di kemudian hari (Montessori, 2008).

Pada jenjang Pendidikan Anak Usia Dini (PAUD), anak usia dini belajar dengan cara bermain. Dengan bermain, anak belajar dan dapat berkembang secara optimal seluruh aspek perkembangannya (Jeffree., McConkey., Hewson., 1995). Bermain menjadi sumber pendidikan yang sangat strategis bagi perkembangan anak usia dini (Sue and Flerr, 2003; Tedjasputra, 2001). Berbicara tentang bermain atau permainan bagi anak, di era globalisasi dewasa ini, dunia permainan anak dibanjiri oleh permainan-permainan yang tidak berakar pada budaya bangsa Indonesia.

Permainan-permainan berbasiskan mesin elektronik menjadi permainan yang sangat akrab bagi anak. Sementara permainan-permainan yang asli tumbuh dan berkembang dari akar kultural masyarakat Indonesia terpinggirkan oleh permainan-permainan modern berbasis mesin dan diimpor dari negara lain. Permainan anak tradisional yang kaya akan nilai-nilai luhur budaya bangsa semakin tidak dikenal oleh anak-anak saat ini. Anak lebih akrab dan paham dengan game online, play station, dan game elektronik lainnya dibandingkan permainan gobagsodor, cublak-cublak suweng, engklek, gandon, jamuran, cim-ciman, umpetan, dan permainan anak tradisional lainnya.

Nilai-nilai pendidikan yang terkandung dalam permainan anak tradisional menjadi tidak mampu berperan dalam pembentukan anak bangsa yang 
berbudaya dan berkarakter Indonesia sebagai akibat tidak dilestarikannya permainan tradisional pada anak. Diperlukan upaya revitalisasi dan rekonstruksi permainan anak tradisional yang tersebar di seluruh pelosok tanah air. Dunia pendidikan berkewajiban mentransformasikan nilai-nilai yang terkandung dalam permainan anak tradisional melalui serangkaian aktivitas pendidikan.

Penelitian ini mengkaji salah satu jenis permainan anak tradisional (dolanan anak) yang berkembang di Jawa dengan corak khas budaya
Banyumas yaitu Cim-Ciman. Penelitian ini diharapkan dapat menjadi bagian proses rekonstruksi dan revitalisasi permainan anak tradisional yang semakin tidak populer di tengah-tengah hegemoni permainan-permainan anak modern berbasis elektronik. Permainan anak tradisional merupakan aset sosial-budaya bangsa yang harus dilestarikan agar nilai-nilai yang terkandung di dalamnya dapat tetap lestari dan berkontribusi secara optimal bagi terbentuknya manusia Indonesia seutuhnya.

\section{METODE PENELITIAN}

Penelitian ini dilaksanakan di Kabupaten Banyumas Jawa Tengah pada tahun 2012. Penelitian ini memakai pendekatan penelitian kualitatif. Jenis penelitiannya adalah studi kasus. Kajiannya diupayakan mendalam, berorientasi pada proses, studi di atas kasus tunggal, serta didasarkan pada asumsi adanya realitas dinamik (Moleong, 2000). Sumber data dalam penelitian ini adalah aktivitas bermain cim-ciman yang dilakukan komunitas anak-anak.

Teknik pengumpulan data dilakukan dengan melakukan pengamatan langsung (observasi partisipan) terhadap aktivitas bermain komunitas anak-anak yang usianya sebaya. Teknik observasi dilakukan untuk mendapatkan data tentang aktivitas anak dalam bermain cim-ciman serta untuk memperoleh gambaran nyata tentang perkembangan anak dalam keseluruhan aspek perkembangan dan aktualisasi nilai karakter pada anak-anak peserta permainan cim-ciman.

Untuk memperoleh data terkait dengan dampak permainan bagi perkembangan dan pembentukan karakter anak dilakukan assesmen dengan teknik observasi terfokus dengan menggunakan instrumen lembar atau pedoman observasi. Dari empat peserta permainan, observasi difokuskan pada tiga anak yang memiliki usia hampir sama yaitu A (6 tahun), N (6 tahun), dan I (6,5 tahun).

Kegiatan assesmen dengan teknik observasi dengan lembar observasi ditujukan terhadap dua sasaran. Pertama, diarahkan untuk melihat perkembangan anak dalam beragam aspek perkembangan yang meliputi aspek perkembangan fisik-motorik, perkembangan bahasa, perkembangan kognitif, perkembangan sosial emosional, dan perkembangan moral. Kedua, untuk menilai tampilan sikap dan perilaku yang mencerminkan nilai budaya dan karakter mulia seperti jujur, disiplin, kreatif, mandiri, tanggung jawab, kepedulan sosial, kerja keras, semangat, menghargai prestasi, bersahabat/komunikatif, cinta damai, dan musyawarah.

Lembar observasi yang digunakan oleh penulis sebagai instrumen asessemen berisi 29 indikator yang diamati yaitu: tidak berbuat curang, menghargai pendapat teman, tertib terhadap aturan bermain, mentaati aturan dan kesepakatan permainan, sungguh-sungguh dalam bermain, memunculkan ide dan cara baru dalam bermain, tidak tergantung dengan teman, antusias dan tidak mudah menyerah, mengakui keberhasilan teman, mau berbicara dengan teman bermain, bekerjasama dengan teman, tidak menimbulkan konflik, membantu teman, melaksanakan tugas bermain dengan sungguh-sungguh, mengikuti musyawarah dengan tekun, dapat melakukan hompimpa dan atau pingsut dengan benar, lincah dan tangkas bergerak, berlari cepat dan terarah, dapat menata genteng tanpa bantuan teman, dapat menemukan tempat perembunyian pemain, dapat menembus pertahanan penjaga dok dengan merobohkan dok (tumpukan genteng), dapat menemukan tempat yang tepat untuk bersembunyi, paham medan/area lokasi permainan, menunjukkan sikap dan perasan senang dan gembira, menggunakan ungkapan bahasa yang tepat ketika bermain, dapat berhitung dengan benar ketika menjadi penjaga dok, ketika menjadi penjaga dok dapat menunjuk pemain sambil mengucapkan cim kearah pemain dengan tepat, mengajukan usul ketika terjadi musyawarah atau diskusi membuat aturan dan kesepakatan, terlibat aktif dalam menyelesaikan masalah, konflik, atau perbedaan pendapat ketika bermain. Adapun 
kategori assesmennya meliputi $\mathrm{SL}=$ selalu, $\mathrm{KK}=$ Kadang-Kadang; dan TP= Tidak Pernah.

Teknik analisis data yang digunakan meliputi analisis data dengan analisis data secara kualitatif dan analisis data dengan teknik statistik deskriptif (Tim Program Pascasarjana, 2012). Analisis secara kualitatif (deskriptif kualitatif) digunakan untuk menganalisis data yang diperoleh dari observasi lapangan terhadap aktivitas permainan dan fenomena perkembangan dan aktualisasi nilai karakter anak. Proses pengolahan dan analisis data dilakukan dengan siklus interaktif sebagaimana yang diajukan oleh Miles dan Huberman yakni memutar dan berulang-ulang sehingga datanya jenuh. Adapun aktivitasnya meliputi reduksi data, penyajian data, dan kesimpulan/verifikasi (Sugiyono, 2009). Analisis data dengan statistika deskriptif digunakan untuk menganalisis data hasil assesmen dengan lembar observasi dalam bentuk perhitungan persentase (\%) dan disajikan dalam bentuk tabel.

\section{HASIL DAN PEMBAHASAN}

\section{Permainan Tradisional Cim-Ciman}

Permainan Cim-Ciman ini merupakan salah satu jenis permainan tradisional anak yang populer di Banyumas. Kata Cim-Ciman merupakan padanan kata dhep-dhepan dan chep-chepan. Dhep = cim berarti adhu ngomong (berbicara berhadap hadapan), ketemu (Tim Penyusun Balai Bahasa, 2001). Pada permainan Cim-ciman, antara pemain dan penjaga dok bertemu dan pada saat bertemu mengucapkan kata cim. Permainan ini biasanya dilakukan oleh anak laki-laki maupun perempuan dengan usia 5 hingga 12 tahun.

Untuk setiap termin atau putaran permainan membutuhkan waktu kurang lebih 15 menit, namun sangat tergantung kemampuan para pemain untuk menyelesaikan. Sementara itu, jumlah termin atau putaran sesuai kesepakatan bersama. Biasanya permainan disudahi jika diantara pemain ada yang sudah lelah, ada keperluan tiba-tiba, atau karena waktu sudah sore atau karena ada kegiatan lain yang harus dikerjakan, pada saat itulah permainan akan disudahi. Lama permainan ditetapkan berdasarkan kesepakatan seluruh anggota permainan. Permainan Cim-Ciman dapat dikategorikan sebagai permainan individu dan beregu.

Pada kategori permainan individu masingmasing anak bermain secara mandiri untuk dirinya tidak tergantung pada kelompok atau regunya. Setiap anak bertanggungjawab terhadap dirinya sendiri, sehingga kalau pada saat dia harus menjadi yang pasang (penjaga dok) maka dia akan menjadi pemasang secara sendirian. Kategori ini biasanya dilakukan jika jumlah anak yang ikut bermain jumlahnya tidak banyak (3-10 anak). Kemenangan dan atau kekalahan bersifat individual.

Pada kategori permainan beregu setiap anak bermain terikat dan bertanggungjawab secara kolektif (terikat kelompok atau regunya). Permainan ini dapat dimainkan secara beregu jika jumlah pemain cukup banyak (misalnya 10 anak ke atas). Jumlah anak yang ikut bermain dibagi ke dalam beberapa regu sesuai kesepakatan sebelum bermain, misalnya 15 anak dibagi menjadi 5 regu sehingga setiap regu berjumlah 3 anak. Jadi setiap termin permainan akan ada satu regu dengan jumlah tiga anak yang akan menjadi penjaga dok, 4 regu lainnya menjadi pemain yang akan berkompetisi untuk merobohkan dok. Kemenangan dan atau kekalahan bersifat kelompok atau regu.

Ada tiga tujuan bermain cim-ciman bagi anak. Pertama, untuk mengisi kegiatan pada waktu luang sehingga waktu yang dimiliki anak tidak terbuang secara percuma. Kedua, memperoleh kesenangan. Ketiga, dengan bermain anak belajar berbagai nilai-nilai hidup dan nilai-nilai budaya serta belajar mengembangkan seluruh aspek dalam dirinya.

Bermain Cim-Ciman bagi anak memiliki banyak manfaat, yaitu anak akan terlatih untuk berlaku jujur, toleransi, disiplin, kerja keras, kreatif, mandiri, semangat, mau menghargai prestasi, bersahabat atau komunikatif, cinta damai, kepedulian sosial, tanggung jawab, musyawarah. Di samping itu, permainan Cim-Ciman juga bermanfaat bagi perkembangan anak. Dengan bermain CimCiman, anak akan terlatih motorik kasar-halusnya. Dengan bergerak, ia akan memiliki otot-otot tubuh yang terbentuk secara baik dan lebih sehat.

Anak juga terlatih sosial-emosionalnya melalui aktivitas sosialisasi, anak merasa senang karena ada teman bermainnya. Pada aspek kognisi anak belajar mengenal atau punya pengalaman mengenai objek-objek tertentu di lingkungannya melalui bermain Cim-Ciman. Anak juga belajar perbendaharaan kata, bahasa, dan berkomunikasi timbal balik. Makin usia bertambah, anak pun 
tertarik memperhatikan sesuatu, memusatkan perhatian dan mengamati. Pada aspek moral, anak terlatih untuk mentaati aturan dan kesepakatan.

Secara garis besar tahapan bermain CimCiman terbagi ke dalam tiga tahapan. Pertama, tahap persiapan. Pada tahap persiapan diawali dengan anak-anak berkumpul di suatu tempat yang lapang, biasanya di halaman rumah salah seorang anak peserta permainan atau di halaman sekolah. Untuk mengumpulkan anak dilakukan dengan dua cara, yaitu secara alamiah mereka datang ke tempat biasa bermain, dan adakalanya saling "nyamper" yaitu mendatangi anak-anak peserta bermain ke rumahnya dan mengajaknya untuk ikut bermain bersama. Kemudian anak-anak membuat aturan atau kesepakatan-kesepakatan tentang permainan yang akan dilakukan. Aturan yang dibicarakan biasanya tentang: siapa yang boleh ikut bermain, permainan secara individu atau beregu, area bermain termasuk jangkauan lokasi yang boleh untuk bersembunyi, dan lama permainan.

Setelah aturan dibuat, anak-anak menyiapkan lokasi atau area bermain kemudian mencari atau mengumpulkan bahan. Bahan-bahan dibutuhkan antara lain pecahan genteng atau batu kecil untuk digunakan sebagai tumpukan dok, dan mencari kapur atau abu sisa pembakaran kayu di dapur. Langkah selanjutnya anak-anak membuat lingkaran di tengah halaman atau area permainan dengan kapur atau abu sisa pembakaran kayu dan menaruh pecahan genteng di tengah-tengah lingkaran.

Kedua, tahap kegiatan bermain. Pada tahap kegiatan bermain Cim-Ciman, dilakukan dengan langkah-langkah sebagai berikut.

1. Permainan putaran pertama, langkahlangkahnya yaitu:

a. Anak-anak peserta permainan melakukan hompimpa dan pingsut. Hompimpa dan pingsut dilakukan untuk menentukan siapa diantara peserta permainan yang menjadi penjaga dok I dan yang menjadi pemain yang bertugas ngumpet atau bersembunyi dan menyerang dok. Peserta yang kalah hompimpa dan pingsut akan menjadi penjaga dok.

b. Penjaga dok menata pecahan genteng di tengah-tengah lingkaran. Pecahan genteng di tata secara bertumpuk ke atas sehingga akan menghasilkan tumpukan pecahan genteng yang disebut dok. Pada saat menata tumpukan genteng pemain lainnya menyaksikan dan berdiri melingkari penjaga dok.

c. Penjaga dog duduk berjongkok di samping dok sambil menelungkupkan wajah/kepala ke atas lutut dengan harapan tidak dapat melihat ke sekitarnya sambil berhitung biasanya 1 sampai 10 dilanjutkan mengucap wis durung (sudah belum), wis durung....diulang sampai berkali-kali, dan para pemain menjawab durung (belum) yang berarti para pemain masih belum bersembunyi. Jika para pemain sudah tidak ada jawaban, berarti para pemain sudah bersembunyi dan penjaga dok sudah boleh mulai mencari persembunyian para pemain. Untuk lebih jelasnya, gambar 1 berikut merupakan ilustrasi dari kegiatan tersebut.

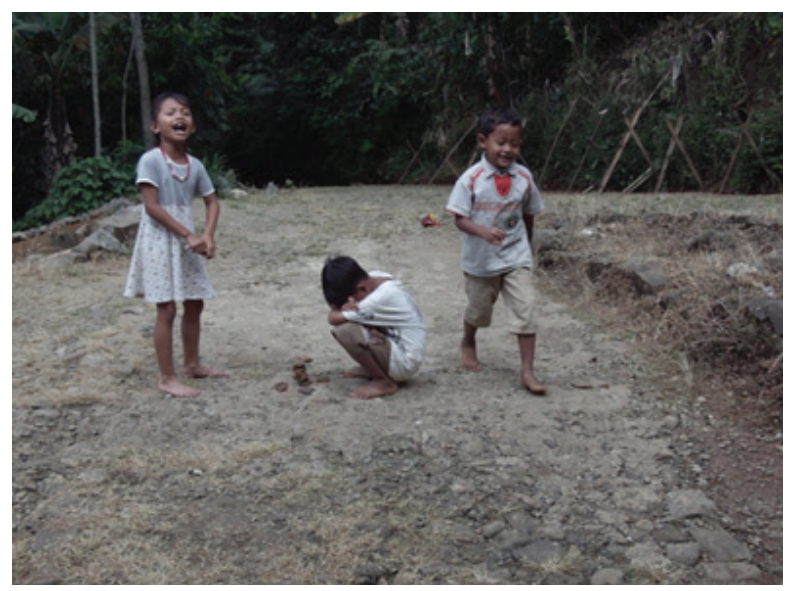

Gambar 1. Penjaga dok sedang menutup wajah agar tidak tahu ke mana pemain bersumbunyi dan para pemain bersiap pergi ke tempat persembunyiannya

d. Penjaga dok mencari pemain yang bersembunyi dengan tetap waspada jangan sampai doknya diserang atau dirobohkan oleh pemain dengan cara ditendang.

e. Pemain yang bersembunyi berusaha mencari kelengahan penjaga dok untuk dapat menembus pertahanan penjaga dok. Pemain akan berusaha agar tidak ketahuan penjaga dok untuk meruntuhkan tumpukan genteng dengan cara ditendang dengan mengucapkan cim.

f. Jika penjaga dok berhasil menemukan pemain di persembunyiannya, si penjaga dok dengan jari telunjuknya menunjuk kearah pemain tersebut dengan menyebut nama pemain kemudian berbalik arah lari kembali menuju dok untuk melangkahi dok sambil mengucap cim dan harus mendahului pemain yang juga lari ke arah dok 
untuk merobohkan tumpukan genteng dengan menendang. Jika berhasil maka pemain yang telah ditemukan tadi kalah dan harus berganti menjadi penjaga dok, sebaliknya jika pemain yang mendahului merobohkan dok maka penjaga dok yang kalah.

2. Permainan putaran kedua, langkah-langkahnya yaitu:

a. Setelah ada pemain yang kalah, maka permainan dilanjutkan ke putaran selanjutnya dengan petugas penjaga dok ganti pemain yang kalah tadi. Begitupun jika dok berhasil dirobohkan oleh salah seorang pemain, maka penjaga dok harus menjadi penjaga dok kembali dan permainan dilanjutkan ke putaran kedua.

b. Untuk melanjutkan permainan ke putaran kedua, seluruh pemain harus kumpul kembali di sekitar dok untuk memulai permainan lagi dengan diawali oleh penjaga dok pada putaran kedua menata pecahan genteng dalam bentuk tumpukan kemudian penjaga dog duduk berjongkok di samping dok sambil menelungkupkan wajah/ kepala ke atas lutut sehingga tidak melihat ke sekitarnya sambil berhitung biasanya 1 sampai 10 dilanjutkan mengucap wis durung (sudah belum), wis durung,... dst dan para pemain menjawab durung (belum) yang berarti para pemain masih belum bersembunyi. Jika para pemain sudah tidak ada jawaban, berarti para pemain sudah bersembunyi dan penjaga dok sudah boleh mulai mencari persembunyian para pemain.

c. Penjaga dok mencari pemain yang bersembunyi dengan tetap waspada jangan sampai doknya dirobohkan oleh pemain dengan cara ditendang.

d. Pemain yang bersembunyi berusaha mencari kelengahan penjaga dok untuk dapat menembus pertahanan penjaga dok. Pemain akan berusaha agar tidak ketahuan penjaga dok untuk meruntuhkan tumpukan genteng dengan cara ditendang dengan mengucapkan cim. Jika penjaga dok berhasil menemukan pemain di persembunyiannya, si penjaga dok dengan jari telunjuknya menunjuk kearah pemain tersebut dengan menyebut nama pemain kemudian berbalik arah lari kembali menuju dok untuk melangkahi dok sambil mengucap cim dan harus mendahului pemain yang juga lari ke arah dok untuk merobohkan tumpukan genteng dengan menendang. jika berhasil maka pemain yang telah ditemukan tadi kalah dan harus berganti menjadi penjaga dok, sebaliknya jika pemain yang mendahului merobohkan dok maka penjaga dok yang kalah.

3. Permainan putaran ketiga dan seterusnya yang dilakukan sebagaimana langkah atau alur permainan termin kedua.

Ketiga, tahap akhir bermain. Tahap akhir bermain terbagi menjadi dua bagian yaitu tahap akhir pada setiap putaran permainan dan seluruh rangkaian bermain. Tahap akhir pada setiap putaran bermain berisi kegiatan: menetapkan penjaga dok termin berikutnya yang ditetapkan apakah dari pemain yang kalah atau penjaga dok lama yang dikalahkan oleh pemain, menetapkan pemenang dan menghitung jumlah point perolehan masingmasing pemain. Pemain yang menang adalah pemain yang dapat meroboh dok, sedangkan jumlah point kemenangan akan dihitung berapa kali merobohkan dok dikurangi berapa kali menjadi pengaja dok pada termin-termin yang telah dilalui.

Selanjutnya tahap akhir seluruh putaran bermain berisi kegiatan: kesepakatan untuk mengakhiri permainan dengan membuat kesepakatan baru kapan akan bermain bersama kembali, menghitung jumlah point kemenangan masing-masing pemain dengan cara menghitung berapa kali dapat merobohkan dok dikurangi berapa kali menjadi penjaga dok dalam seluruh termin permainan, dan terakhir menetapkan pemain yang mendapat juara (sang pemenang) permainan.

Dalam permainan Cim-Ciman, orang tua dapat berperan sebagai pengarah, pembimbing bagi anak, sekaligus membantu menyediakan peralatan yang dibutuhkan dalam permainan. Orang tua juga dapat berperan sebagai wasit atau penengah tatkala diantara pemain terjadi perselisihan pendapat atau percekcokan. Selain itu juga berperan sebagai pengawas ketika anak bermain. Bahkan pada kondisi tertentu orang tua dapat berperan sebagai teman bermain bagi anak.

Teman sebaya juga dapat berperan sebagai partner bermain. Permainan ini dilakukan karena ada anak-anak yang sebaya berkumpul dan bersepakat untuk bermain Cim-Ciman bersama. Di samping itu, teman sebaya juga dapat berperan sebagai tutor sebaya (peer teaching) dengan cara mentransformasikan pengalaman-pengalamannya 
dalam bermain Cim-Ciman terutama bagi anak yang baru ikut bermain Cim-Ciman (pendatang baru). Biasanya pendatang baru adalah anak yang usianya relatif paling muda diantara pemain atau ada anak dari luar kampung/desa atau komunitas anak tersebut yang kebetulan ikut bermain.

\section{Aktualisasi Nilai-Nilai Karakter dalam Permainan Tradisional Cim-Ciman}

Sebagaimana diuraikan di atas, bahwa permainan Cim-Ciman memiliki manfaat yang beragam bagai perkembangan anak. Untuk mengetahui pengaruh bermain bagi upaya stimulasi perkembangan anak, diperlukan adanya assesmen (penilaian) terhadap anak yang menjadi peserta permainan. Berdasarkan hasil observasi langsung pada saat anak-anak bermain Cim-Ciman, perkembangan aspek fisik-motorik setidaknya dapat dilihat melalui beberapa aktivitas anak mulai dari dapat melaksanakan hompimpa dan pingsut, bergerak dengan lincah dan tangkas ke sana dan kemari, berlari dengan cepat, dan dapat menata pecahan genteng menjadi tumpukan yang rapi.

Aspek perkembangan kognitif diantaranya anak mampu memahami medan atau area permainan, dapat menemukan tempat persembunyian pemain, menunjuk nama pemain dengan tepat, dan dapat menemukan tempat yang tepat untuk bersembunyi. Untuk aspek bahasa terlihat ketika anak dapat menggunakan ungkapan bahasa dengan tepat untuk memanggil, menunjuk dan berkomunikasi dengan teman, serta mengajukan usul pada saat berunding untuk membuat aturan dan kesepakatan.

Pada aspek sosial emosional terlihat anak menunjukan sikap dan perasaan senang dan gembira, terlibat aktif dalam perdebatan menyelesaikan konflik dan perbedaan pada saat bermain. Adapun perkembangan aspek moral ditunjukan oleh ketaatan anak-anak terhadap aturan permainan, dan tidak melakukan kecurangan.

Selain perkembangan pada aspek-aspek di atas, berkembang pula budaya dan karakter jujur dengan tidak melakukan curang dalam bermain, nilai toleransi dengan berkembangnya kemampuan menghargai pendapat teman, budaya dan karakter disiplin diwujudkan dengan tertib dan taat terhadap aturan permainan, kerja keras diwujudkan dengan kesungguhan dan tidak mudah menyerah dalam bermain, berkembang pula kreativitasnya, mandiri dengan tidak tergantung pada tema, berkembang sikap semangat dan antusias dalam melakukan sesuatu, bekerjasama dan komunikatif dengan teman, dan tanggung jawab yang tinggi dalam menyelesaikan tugas.

Hasil assesmen menggunakan lembar observasi dengan 29 indikator disajikan dalam tabel 1 berikut.

Tabel 1. Indikator Perkembangan Anak

\begin{tabular}{ccccccc}
\hline \multirow{2}{*}{ Nama } & \multicolumn{6}{c}{ Kategori } \\
\cline { 2 - 7 } & \multicolumn{2}{c}{ Selalu } & \multicolumn{2}{c}{ Kadang-kadang } & \multicolumn{2}{c}{ Tidak Pernah } \\
\cline { 2 - 7 } & $\mathbf{f}$ & $\%$ & $\mathbf{f}$ & $\%$ & $\mathbf{f}$ & $\%$ \\
\hline $\mathrm{A}$ & 20 & 69 & 7 & 24 & 2 & 7 \\
$\mathrm{~N}$ & 22 & 76 & 7 & 24 & 0 & 0 \\
$\mathrm{I}$ & 24 & 83 & 5 & 17 & 0 & 0 \\
\hline
\end{tabular}

Berdasarkan tabel 1 di atas, dari 29 item indikator diperoleh data: (a) untuk $A$, selalu 20 item (69\%), kadang-kadang 7 item (24\%) dan tidak pernah $2(7 \%)$; (b) untuk N, selalu 22 item (76\%), kadangkadang 7 item (24\%) dan tidak pernah $0(0 \%)$; dan (c) untuk I, selalu 24 item (83\%), kadang kadang 5 item $(17 \%)$ dan tidak pernah $0(0 \%)$. Dengan demikian, diperoleh informasi bahwa baik $\mathrm{A}, \mathrm{N}$, dan I selama permainan Cim-ciman selalu menampilkan perilaku sebagaimana item-item indikator dalam tingkat yang tinggi yaitu di atas $75 \%$ item indikator selalu ditampilkan. Dengan kategorisasi: 0\%-33\% kategori rendah, 34\% - 66\% kategori sedang, dan $67 \%-100 \%$ kategori tinggi.

Hal ini mengandung makna bahwa permainan Cim-ciman dapat dipergunakan untuk melatih dan menstimulasi perkembangan anak dalam beragam aspek yaitu fisik motorik, bahasa, kognitif, sosial emosional, moral. Selain itu juga dapat dipergunakan untuk menanamkan nilai-nilai budaya dan membangun karakter seperti jujur, disiplin, kreatif, mandiri, tanggung jawab, kepedulian sosial, kerja keras, semangat, menghargai prestasi, bersahabat atau komunikatif, cinta damai, dan musyawarah.

Tabel 2 berikut adalah nilai-nilai karakter yang diaktualisasikan melalui permainan tradisional CimCiman di Banyumas berdasarkan hasil observasi peneliti. 
Tabel 2. Nilai Karakter dan Deskripsi Perilaku yang Dilestarikan dengan Permainan Dolanan Anak Cim-ciman

\begin{tabular}{|c|c|}
\hline $\begin{array}{c}\text { Nilai } \\
\text { Karakter }\end{array}$ & Deskripsi \\
\hline Kejujuran & $\begin{array}{l}\text { Perilaku anak yang berupaya menjadi } \\
\text { orang yang selalu dapat dipercaya dengan } \\
\text { mengakui kekeliruan. }\end{array}$ \\
\hline Toleransi & $\begin{array}{l}\text { Sikap dan tindakan yang menghargai } \\
\text { perbedaan pendapat di antara teman } \\
\text { bermain. }\end{array}$ \\
\hline Disiplin & $\begin{array}{l}\text { Perilaku tertib dan patuh pada berbagai } \\
\text { aturan dan kesepakatan dalam bermain } \\
\text { bersama. }\end{array}$ \\
\hline Kerja Keras & $\begin{array}{l}\text { Perilaku dan sikap sungguh-sungguh dalam } \\
\text { bermain agar menjadi pemenang. }\end{array}$ \\
\hline Kreatif & $\begin{array}{l}\text { Melakukan aktivitas bermain dengan teknik } \\
\text { kreatif agar dapat memperoleh point. }\end{array}$ \\
\hline Mandiri & $\begin{array}{l}\text { Sikap dan perilaku yang tidak mengandalkan } \\
\text { bantuan atau pertolongan teman. }\end{array}$ \\
\hline Semangat & $\begin{array}{l}\text { Sikap dan tindakan antusias, sungguh- } \\
\text { sungguh dalam bermain dan tidak mudah } \\
\text { menyerah. }\end{array}$ \\
\hline $\begin{array}{l}\text { Menghargai } \\
\text { Prestasi }\end{array}$ & $\begin{array}{l}\text { Sikap dan tindakan anak mengakui dan } \\
\text { menghormati keberhasilan lawan main. }\end{array}$ \\
\hline $\begin{array}{l}\text { Bersahabat/ } \\
\text { komuniktif }\end{array}$ & $\begin{array}{l}\text { Tindakan yang memperlihatkan pendapat } \\
\text { teman, senang berbicara dengan teman } \\
\text { bermain, dan kesediaan bekerja sama } \\
\text { dengan teman. }\end{array}$ \\
\hline Cinta Damai & $\begin{array}{l}\text { Sikap, perkataan, dan tindakan yang selalui } \\
\text { dapat membaut teman bermain merasa } \\
\text { senang, dan menghindari konflik meskipun } \\
\text { dalam suasana kompetisi. }\end{array}$ \\
\hline $\begin{array}{l}\text { Kepedulian } \\
\text { sosial }\end{array}$ & $\begin{array}{l}\text { Sikap dan tindakan saling membantu dan } \\
\text { bekerjasama dalam bermain. }\end{array}$ \\
\hline $\begin{array}{l}\text { Tanggung } \\
\text { jawab }\end{array}$ & $\begin{array}{l}\text { Sikap dan perilaku penuh kesungguhan } \\
\text { dalam melaksanakan keputusan sebagai } \\
\text { tugas dan kewajibannya dalam permainan. }\end{array}$ \\
\hline Musyawarah & $\begin{array}{l}\text { Tindakan dalam mengambil keputusan } \\
\text { dilakukan dengan cara bermusyawarah untuk } \\
\text { mencapai suatu kesepakatan bersama. }\end{array}$ \\
\hline
\end{tabular}

Karakter manusia akan terbangun dari proses pembudayaan nilai-nilai mulia dalam kehidupan (Lickona, 1992). Nilai-nilai tersebut sebagai keseluruhan sistem berpikir, nilai, moral, norma, dan keyakinan (belief) manusia yang dihasilkan masyarakat. Sistem berpikir, nilai, moral, norma, dan keyakinan itu adalah hasil dari interaksi manusia dengan sesamanya dan lingkungan alamnya. Teori konstruktivis sosial Piaget dan Vigotsky menyatakan bahwa anak mengkonstruksi dan membangun perilakunya sebagai hasil belajar dari pengalaman dalam aktivitas interaksi sosial (Morrison, 2012). Pengembangan pengetahuan dan perilaku anak terjadi dalam konteks hubungan sosial dengan orang dewasa dan teman sebaya. Melalui permainan bersama teman sebaya akan terbentuk sikap dan perilaku anak sebagai hasil konstruksi atas pengalaman dan interaksi sosialnya.

Sistem berpikir, nilai, moral, norma dan keyakinan itu digunakan dalam kehidupan manusia dan menghasilkan sistem sosial, sistem ekonomi, sistem kepercayaan, sistem pengetahuan, teknologi, seni, dan sebagainya. Manusia sebagai makhluk sosial menjadi penghasil sistem berpikir, nilai, moral, norma, dan keyakinan; akan tetapi juga dalam interaksi dengan sesama manusia dan alam kehidupan, manusia diatur oleh sistem berpikir, nilai, moral, norma, dan keyakinan yang telah dihasilkannya.

Ketika kehidupan manusia terus berkembang, maka yang berkembang sesungguhnya adalah sistem sosial, sistem ekonomi, sistem kepercayaan, ilmu, teknologi, serta seni. Pendidikan merupakan upaya terencana dalam mengembangkan potensi peserta didik, sehingga memiliki sistem berpikir, nilai, moral, dan keyakinan yang diwariskan masyarakatnya dan mengembangkan warisan tersebut ke arah yang sesuai untuk kehidupan masa kini dan masa mendatang.

Melalui permainan Cim-ciman, anak secara aktif mengembangkan potensi dirinya, melakukan proses internalisasi, dan penghayatan nilai-nilai menjadi kepribadian mereka dalam bergaul di masyarakat, mengembangkan kehidupan masyarakat yang lebih sejahtera, serta mengembangkan kehidupan bangsa yang bermartabat.

Bermain memiliki peran penting dalam perkembangan anak pada hampir semua aspek perkembangan secara holistik-integratif, baik aspek fisik-motorik, bahasa, kognitif, sosial emosional, dan moral. Dalam permainan Cim-ciman, seluruh aspek perkembangan anak mendapatkan stimulasi melalui serangkaian aktivitas bermain yang dilakukan anak. Berikut adalah optimalisasi pada aspek-aspek perkembangan anak melalui permainan tradisional Cim-ciman.

\section{Perkembangan Fisik Motorik}

Bermain Cim-ciman dapat mengembangkan 
kemampuan fisik motorik anak. Dalam bermain Cim-ciman, anak bergerak dan berlari secara bebas, lincah, dan energik sehingga mampu menstimulasi perkembangan fisik motoriknya, baik motorik kasar maupun motorik halus. Dalam permainan ini, anak dituntut untuk banyak bergerak dan berlari. Bergerak dan berlari menjadi salah satu unsur pokok dalam permainan ini.

\section{Perkembangan Bahasa}

Bermain Cim-ciman dapat mengembangkan kemampuan anak dalam aspek bahasa. Dalam permainan ini bahasa digunakan untuk berkomunikasi dengan teman bermain atau sekedar untuk menyatakan pikirannya. Bahasa digunakan mulai dari awal bermain, dalam proses bermain sampai saat mengakhiri permainan.

Pada awal permainan, bahasa digunakan untuk proses hompimpa, diskusi membuat kesepakatan dan aturan bermain. Sedangkan dalam proses bermain, bahasa digunakan pada saat penjaga dok (dok berupa tumpukan pecahan genteng atau bisa menggunakan batubatu kecil) dapat menemukan pemain di tempat persembunyiannya dengan menyebut nama sambil menunjuk jari ke arah pemain yang ditemukan serta mengucapkan cim dengan melompat di atas tumpukan batu kecil atau pecahan genteng, yang berarti pemain yang ditemukan tadi telah kalah dalam sesi permainan saat itu. Bagi pemain, bahasa dalam proses bermain digunakan pada saat mengucapkan cim sambil kakinya mendorong tumpukan pecahan genteng supaya roboh atau menendang tumpukan pecahan genteng atau tumpukan batu kerikil yang menandakan bahwa pemain tersebut menang dan penjaga dok harus kembali menata tumbukan genteng dan menjadi pemasang kembagi.

Di samping itu, bahasa juga digunakan untuk berembuk, diskusi menyelesaikan permasalahan antar pemain dan pemain dengan penjaga dok ketika di tengah permainan terjadi perselisihan. Pada akhir permainan, bahasa digunakan untuk membuat kesepakatan bersama bahwa permainan diakhiri serta anak akan diskusi membuat kesepakan kapan akan bermain bersama kembali dan tempat dimana bermain akan dilaksanakan. Dengan proses seperti ini, aspek perkembangan bahasa dapat distimulasi perkembangannya.

\section{Perkembangan Kognitif}

Bermain mengembangkan kemampuan kognitif. Bermain cim-ciman menyediakan kesempatan kepada anak untuk berinteraksi dengan objek.Anak memiliki kesempatan untuk menggunakan inderanya, seperti melihat, mendengarkan, menyentuh, menunjuk, menendang atau medorong dengan kaki. Dari proses seperti ini, anak memperoleh fakta-fakta, informasi dan pengalaman yang akan menjadi dasar untuk berpikir abstrak. Penelitian Hoorn (1993) menunjukkan bahwa bermain memiliki peran yang sangat penting dalam mengembangkan kemampuan berpikir logis, imajinatif, dan kreativitas.

\section{Perkembangan Moral}

Permainan Cim-ciman dilaksanakan dengan seperangkat aturan. Tanpa aturan maka permainan tidak akan berjalan dengan baik. Di mana setiap permainan memiliki aturan. Bermain Cim-ciman akan melatih anak dalam menyadari adanya aturan dan pentingnya mematuhi aturan. Hal ini merupakan tahap awal dari perkembangan moral.

5. Perkembangan Sosial Emosional

Dalam bermain, anak berinteraksi dengan anak lain. Interaksi tersebut mengajarkan anak bagaimana merespon, memberi dan menerima, menolak atau setuju ide dan perilaku anak yang lain. Dengan demikian, akan mengurangi egoisme anak dan mengembangkan kemampuan sosial. Kemampuan interaksi dan komunikasi sosial anak menjadi dengan dibarengi berkembangnya aspek emosinya.

Agar permainan anak tradisional ini dapat digunakan untuk mengoptimalkan perkembangan dan karakter anak, penting diantisipasi kemungkinan munculnya resiko atau dampak negatif yang ditimbulkan dari permainan anak berikut ini.

1. Waktu anak dihabiskan untuk fokus pada satu permainan

Terlalu banyak waktu yang digunakan anak untuk bermain dan fokus pada satu permainan membuatnya merasa bosan, dan kelelahan. Dengan melakukan permainan yang berulang-ulang kegembiraan dan kesenangan yang ditimbulkan oleh bermain semakin lama semakin menghilang. Kebosanan, kejenuhan dan kelelahan akan membuat anak malas melakukan kegiatan lainnya di luar permainan ini, dan menjadikan kinerja anak menjadi tidak optimal. Oleh karena itu, diperlukan 
ketanggapan para orang tua atau pengasuh anak untuk secara aktif mendampingi dan memberikan kontrol terhadap jumlah waktu yang digunakan anak dalam bermain.

2. Ketidakseimbangan antara bermain untuk sosialisasi dan bermain sendiri

Dengan bermain bersama teman sebaya, anak dapat mengembangkan kemampuan personal dan penyesuaian dirinya. Anak dapat belajar bagaimana berinteraksi dengan anak lain. Tetapi bila anak terpaku pada kegiatan bermain bersama, dan kurang melibatkan diri pada kegiatan bermain sendiri, anak akan mengalami kesulitan untuk melakukannya bila memang diperlukan. Pada bermain sendiri bisa juga menyenangkan dan membawa dampak positif bagi perkembangan personal dan emosi anak.

3. Alat permainan yang dapat membahayakan keselamatan anak

Permainan ini menggunakan alat yaitu pecahan genteng. Perlu dicermati bahwa sangat dimungkinkan ada aspek yang berbahaya dengan alat ini mengingat pecahan genteng mengandung unsur ketajaman yang dapat melukai kaki anak, karena untuk merobohkan dok yang berupa tumbukan genteng dalam permainan ini dilakukan dengan cara menendang dengan kaki telanjang. Oleh karena itu, agar hasilnya tidak membahayakan anak perlu dicarikan alternatif alat atau media lain yang tidak berbahaya agar bisa lebih optimal hasilnya.

4. Ketidakseimbangan perhatian dan bimbingan orang tua atau orang dewasa

Ditemukan dua fenomena yang cenderung kurang ideal terkait perhatian dan bimbingan yang seharusnya diberikan oleh orang tua atau orang dewasa lainnya terhadap anak yang sedang bermain. Fenomena pertama, seringkali orangtua atau orang dewasa lainnya menganggap bahwa anak tahu secara langsung bagaimana bermain sehingga mereka tidak memberitahu cara memainkannya. Fenomena kedua, ada orangtua yang berpandangan anak tidak akan senang bermain bila tidak diajarkan bagaimana cara memainkannya. Kedua fenomena ini sangatlah merugikan anak, karena mempengaruhi rasa senang yang diperolehnya melalui bermain sehingga pada akhirnya akan mempengaruhi dampak positif bagi anak. Anak yang terlalu sedikit atau tidak sama sekali mendapatkan bimbingan tentang cara bermain akan cepat bosan karena tidak paham cara bermain, sedangkan anak yang terlalu banyak mendapatkan instruksi akan menjadikan minim kreativitas, muncul sikap ketergantungan terhadap bantuan dan bimbingan orang lain.

\section{PENUTUP}

\section{Kesimpulan}

Permainan Cim-ciman dapat dipergunakan untuk melatih dan menstimulasi perkembangan anak dalam beragam aspek secara holistikintegratif; baik aspek fisik, motorik, bahasa, kognitif, sosial emosional, dan moral. Selain itu dapat dipergunakan untuk menanamkan dan membentuk nilai-nilai budaya dan membangun karakter anak seperti jujur, disiplin, kreatif, mandiri, tanggungjawab, kepedulian sosial, kerja keras, semangat, menghargai prestasi, bersahabat atau komunikatif, cinta damai, dan musyawarah. Oleh karena itu, orangtua dan para pendidik pendidikan anak usia dini dapat mengoptimalkan permainan tradisional khususnya Cim-ciman untuk perkembangan dan pembentukan karakter anak. Permainan ini dapat dipergunakan untuk evaluasi perkembangan dan karakter anak, karena di dalam kegiatan bermain ini, perilaku yang tampil lebih murni, alami, dan apa adanya tanpa dibuat-buat.

\section{Saran}

Berdasarkan urgensi temuan penelitian sebagaimana paparan di atas diperlukan kebijakan nasional untuk rekonstruksi dan revitalisasi permainan anak tradisional (dolanan anak) yang tersebar di seluruh nusantara dengan segala kekhasan budayanya, untuk selanjutnya dijadikan sebagai menu kurikulum pendidikan anak usia dini sebagai proses pewarisan dan pelestarian warisan budaya bangsa. Kepada para orang tua yang memiliki anak usia dini untuk mengenalkan beragam permainan anak tradisional yang ada di daerahnya. Kepada pendidik lembaga pendidikan anak usia dini untuk secara aktif mengenalkan dan menjadikan permainan anak tradisional sebagai prioritas jenis permainan yang diajarkan dalam kegiatan belajar mengajar. Kepada para peneliti untuk melakukan kajian lanjutan terhadap permainan tradisional yang tersebar diberbagai daerah dalam berbagai perspektif dan ragam jenis penelitian. 


\section{DAFTAR PUSTAKA}

Al-Jabiri, M. A. (2003). Kritik kontemporer atas filsafat Arab-Islam. (Moch. Nur Ichwan, penterjemah). Yogyakarta: Islamika.

Barker, C. (2004). Cultural studies teori \& praktik. (Nurhadi, penterjemah). Yogyakarta: Kreasi Wacana.

Dockett, S., Flerr, M. (2003). Play and pedagogy in early childhood bending rules. Cambridge: Harvard University Press.

Hurlock, E. B. (2007). Perkembangan anak, jilid 1. (Mila Rachmawati dan Anna Kuswanti, penterjemah). Jakarta: Erlangga.

Jeffree, D. M., McConkey, R., Hewson, S. (1995). Let me play. London: A Condor Book Souvenir Press.

Keenan, T.,\& Evans, S. (2009). An introduction to child development. London: Sage Foundations of Pasychology.

Lickona, T. (1992). Educating for character how our schools can teach respect and responsibility. New York: Bantam Books.
Mayles, J. R. (Ed.). (1995). The excellence of play. Backingham-Philadelphia: Open University Press.

Moleong, L. J. (2000). Metodologi penelitian kualitatif. Bandung: Remaja Rosdakarya.

Montessori, M. (2008). The absorbent mind pikiran yang mudah menyerap. (Dariyatno, penterjemah). Yogyakarta: Pustaka Pelajar.

Morisson, G. S. (2012). Dasar-dasar pendidikan anak usia dini. Suci Romadhona \& Apri Widiastuti, penterjemah). Jakarta: Indeks.

Sugiyono. (2009). Metode penelitian pendidikan pendekatan kuantitatif, kualitatif, dan R\&D. Bandung: Alfabeta.

Tedjasputra, M. S. (2001). Bermain, mainan, dan permainan. Jakarta: Grasindo.

Tim Penyusun Balai Bahasa Yogyakarta. (2001). Kamus Basa Jawa (Bausastra Jawa). Yogyakarta: Kanisius.

Tim Program Pascasarjana. (2012). Buku pedoman penulisan tesis dan disertasi PPS UNJ. Jakarta: PPs UNJ Press. 